\title{
Poland and Germany in the European Union
}

The Multidimensional Dynamics of Bilateral Relations

\section{Edited by \\ Elżbieta Opilowska and Monika Sus}

First published 2021

ISBN: 978-0-367-49079-9 (hbk)

ISBN: 978-0-367-49561-9 (pbk)

ISBN: 978-1-003-04662-2 (ebk)

\section{Bilateralism within the European Union}

Examining the explanatory power of horizontal Europeanisation and interdependence

Joanna Dyduch

CC BY-NC-ND 4.0

DOI: $10.4324 / 9781003046622-3$

The funder for this chapter is Uniwersytet Jagielloński.

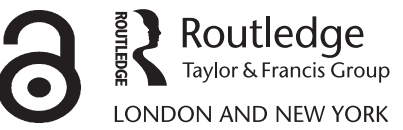




\section{Bilateralism within the European Union Examining the explanatory power of horizontal Europeanisation and interdependence}

Joanna Dyduch

\section{Introduction}

Contemporary bilateralism is a 'dyadic relationship' (Renard, 2015) and, as a research subject, requires methodological openness and analytical vigilance. The point of departure for this chapter is the assumption that, as the current shape of European integration does not leave much space for EU member states to operationalise their relations with one another without any reference to the EU institutional and normative framework, the concept of Europeanisation may serve as a valuable tool in researching the bilateralism within the European Union.

The European studies literature elaborates widely on the vertical processes of mutual exchanges and influences between the EU member states and the 'Brussels centre' (EU institutions) (Alecu de Flers \& Müller, 2012; Ladrech, 2010; Moumoutzis, 2011; Moumoutzis \& Zartaloudis, 2016; Pomorska, 2011; Radaelli, 2004; Saurugger \& Radaelli, 2008; Smith, 2000, 2004). However, those bidirectional processes, termed 'downloading' and 'uploading' Europeanisation, do not fully capture and explain the complexity and dynamics of the EU's governance system. Horizontal interactions between member states, which might be particularly relevant for studying bilateralism in the multilateral context, are somewhat overlooked. Very few authors have discussed this additional dimension of Europeanisation, first termed by Howell as 'cross-loading' (Howell, 2004: 48-49; see also Major, 2005: 181182; Aggestam \& Bicchi, 2019: 1-2).

The epistemological exploration of cross-loading Europeanisation can be somewhat complementary to academic debates on how to study bilateralism between the EU member states (My, Verchere \& Bertrand, 2009; Krotz \& Schild 2012, 2018; Uilenreef, 2016), as it indicates the significance of the European level with more precision. Cross-loading Europeanisation is defined in this chapter as an 'ongoing interactive and mutually constitutive process of change linking national and European levels' (Major, 2005: 177). It may involve the transfer of solutions and best practices between EU member states, which may occur with or without the direct involvement of supranational EU institutions.

DOI: $10.4324 / 9781003046622-3$ 
Hence, the chapter aims to introduce horizontal Europeanisation as a tool for analysing bilateral relations between the EU member states. However, at a time of consecutive crises (financial, economic, social and migration, and now the pandemic), shrinking resources, stronger competition, rising Euroscepticism and political elites' increasing reluctance towards further integration (Hadeed \& Sus, 2020), power-based relations ${ }^{1}$ seem to prevail over communitarian coexistence as nation states once again assert their dominant position. These new developments have changed the framework for intersystem relations in favour of horizontal interaction at the expense of the supranational vertical Europeanisation process. Although states are not and have never been the only international actors, they are the key - primary players of the system (Waltz, 1979: 93).

Having this in mind, bilateralism within the EU will be examined here through the lens of neorealist theory. Its conceptual framework reflects today's reality, as realist terminology is once again relevant (Joseph \& Wight, 2010; Skordas, 2018; Herbut \& Kunert-Milcarz, 2017). When analysing relations between international actors, apart from categories such as 'interest' and 'power', realists emphasise the epistemological category of 'interdependence' (Waltz, 1979) or its variation, 'dependence', which results from a sharp asymmetry in states' capabilities.

Europeanisation and interdependence are proposed in this chapter as explanatory independent variables to be utilised for the study of bilateralism in the context of European integration.

The chapter consists of two parts. In the first, a recapitulation and further conceptualisation of Europeanisation is offered. Since the goal is to contribute to the theoretical discussion on how to examine bilateral relations between EU member states, particular attention is paid to the horizontal cross-loading processes. The second part reflects on the importance of interdependence. Although it is a causal factor that might affect any relations between states, this chapter focuses on how it is shaped specifically by European integration.

\section{Multidimensional Europeanisation: a tool to study bilateralism within the $\mathbf{E U}$}

If the cross-loading dimension of Europeanisation is to be used as a tool for studying bilateral relations, it is necessary to begin with a reflection on the nature of the European Union's governance system as a component of a larger international system and the framework for bi- and multilateral relations among member states (Hill \& Smith, 2011: 470). As European integration develops, policy-making processes in the EU evolve in a complex scheme of multi-level governance in which states interact with each other and with EU institutions in multiple forums and in a variety of ways (Bátora \& Hocking, 2009: 167). The institutionalisation of cooperation at the EU level has facilitated the creation of a distinct system (Olsen, 2002: 929). A culture that sought consensus has facilitated the reaching of agreements and 
has constantly reproduced the system's structures. These, in turn, have taken the form of formalised and non-formalised interactions between EU member states (Marciacq, 2012), whose number has increased significantly over time. The EU's enlargement process has been changing the system's structure, reshaping the constellation of alliances and ad hoc coalitions in the EU.

The system's stability and efficiency depend on its legitimisation by its constitutive elements (member states), as manifested both in joint actions (also bilateral) and in bilateral cooperation between the member states, aiming to deepen the integration (e.g. Franco-German partnership). Conversely, contestation of the system's norms and/or disengagement from its core activities lead to its partial or full incoherence, and possibly even deconstruction. The more countries question the norms and rules, the greater the impact of such opposition. The realisation of each alternative tremendously influences the course and dynamic of bilateralism within the EU. Whereas most examples from the history of European integration can be described as in-between options, Brexit and some member states' positions towards recent challenges (the migration crisis and the pandemic) prove that even the extreme scenarios are entirely possible.

Even though the process of integration within the EU is very advanced, the organisation of the system's internal structure is still very different from the hierarchical state order. In the early 1990s Waltz wrote that 'the EC has moved so far towards unity that it cannot pull back, at least not very far ... but it ... has moved so far towards unity that it can go no further' (Waltz, 1993). It seems that his assertion is even more appropriate today than at the time it was formulated. As for European integration, the easier steps were taken first, the more difficult ones took more time and the most difficult ones, related to the ceding of national sovereignty, have been left for a convenient moment - which, so far, has failed to come. Although previous crises may have spurred cooperation, the most recent disagreements among states have led to an increase in resistance to further integration.

From the structural realist's perspective, the EU is an emanation of its member states' will. Its structural-formative power depends on what states intend, and it is, above all, a tool used by national governments to pursue their national interests.

In the light of the above explanation, the European Union is not an actor per se. Hence, in this chapter it serves as a framework for interstate interactions rather than as an independent entity. Its governance system comprises shared norms, commonly recognised standards of behaviours and institutionalised ways of doing things, and is empowered by shared beliefs, visions and - most importantly - interests. This basic assumption shifts our attention to the ongoing debate on the nature, mechanisms and instruments of the processes occurring within the EU. This is why the next section seeks to reflect on the academic discourse around the 'Europeanisation' concept.

Europeanisation is both an observable process and a theoretical concept taking into account the dynamics and multidimensional nature of the 
phenomena to be examined. Literature on Europeanisation recognises four dimensions to the process: bottom-up (uploading); top-down (downloading); ad extra (beyond Europe); and cross-loading (between the states) (e.g. Ladrech, 2010; Radaelli, 2004; Smith, 2004).

The circular processes of Europeanisation occur in several dimensions simultaneously. The ad extra dimension corresponds to states' activity at the global level, and downloading, uploading and - most importantly in the context of this chapter - the cross-loading dimensions refer to the processes and relations appearing within the EU.

Downloading and uploading - the vertical dimensions extensively discussed in academic literature (Featherstone \& Radaelli, 2003; Howell, 2004; Major, 2005; Vink \& Graziano, 2007) - involve primarily member states' relations with EU institutions. Governments' successful projection of national interests at the supranational level is accompanied by the establishment of increasingly advanced governance mechanisms. Naturally, this has consequences for the way bilateral relations between member states are shaped (Hill \& Smith, 2011: 270-271). Reflecting the advanced stage of European integration, member states' bilateral relations have lost some of their foreign policy nature and have, instead, become somewhat internalised. Member states' public policies (in economics, environmental and energy policy, and also in foreign policy) have gained an important EU dimension. This is so because certain areas of bilateral relations within the EU are now regulated at the supranational level, which in turn reinforces the horizontal policy coordination across national governments. In areas where there are no relevant EU regulations, relations between member states are managed either through multilateral intergovernmental agreements or through bilateral agreements. However, these must not contradict any provisions of the acquis communautaire.

EU membership is conducive to the intensification and systematisation of contacts between member states, both logistically/organisationally and in terms of the socialisation process. Regular meetings of national representatives, particularly in the EU Council and the European Council, create a specific organisational culture characterised by a consensual, pluralistic and collective approach to decision-making. The contacts between the EU member states embedded in the EU's system of governance may take on a bilateral or multilateral variant. Consequently, the impact and relevance of European integration for bilateralism is strengthened through continuous, intense communication and the exchange of perspectives and information, which takes place on a daily basis in the Permanent Representatives Committee, the Political and Security Committee and numerous other working groups within the EU Council (Bátora \& Hocking, 2009).

Working within the EU framework, national representatives can form coalitions not only among themselves but also with certain institutions - such as, for instance, if they want to justify and legitimise their actions in the eyes of other countries, or even their own societies. By acting together, member states try to strengthen their positions vis-à-vis other actors (both states and 
supranational EU institutions). Thus, the varied (in terms of both form and content) dynamics of the EU system affect member states' policies and, consequently, bilateral relations between them.

The above observation is the first step to taking a closer look at crossloading - a horizontal policy transfer between the European Union's member states. Although Howell suggests that cross-loading Europeanisation did not necessarily involve the European level directly and could be limited to 'learning from and taking on other member state policies without EU involvement' (2004: 48), it almost always entails at least some indirect influence on the part of the Union. This happens when member states use the EU's legal and institutional framework in order to shape relations between themselves. To illustrate the situation, one may recall the provisions of the European treaties, stating that the EU Court of Justice shall have jurisdiction in any dispute between member states (Treaty on the Functioning of the European Union, 2009: article 273). Alternatively, member states interacting with each other may jointly shape the structure of the EU system of governance, so that it reflects their national preferences and interests as much as possible. This happens regardless of the coalition-building practice on the occasion of negotiating the Multiannual Financial Framework.

What is more, bilateralism within the EU may stimulate or slow down the integration process. Bilateral interactions certainly have an impact on negotiations at the multilateral EU level (Pannier, 2020: 28). At the same time, the supranational agenda (such as the negotiations of budgetary issues, which put both EU institutions and member states in an intense, vertical interaction) strengthens and intensifies the 'bilateral ties outside the formal negotiation going on in the Council in Brussels' (Uilenreef, 2016: 440), as governments seek to coordinate their positions. Moreover, as Uilenreef highlights, information incentives received through bilateral contacts have had a crucial impact on the preferences and behaviours of member states at the EU level (Uilenreef, 2016: 441). In return, the EU's system of governance, with its structural and operational complexity, directly or indirectly impacts the member states' relations that occur in bilateral form.

Depending on the nature and character of bilateralism, its course and nature may lead to fairly different results. On the one hand, well-established and constructive bilateral relations embedded into larger multilateral structures result from the stabilisation of the system. Its internal coherence, in turn, enables the implementation of joint projects and tasks. It can be said that the relative stability (safety) and prosperity (welfare) of the EU favours grouping consolidation. In times of prosperity, cooperation is easier and the will to contribute to joint undertakings is greater. On the other hand, conflictual bilateral relations (between at least two major players) may block multilateral cooperation as such. Furthermore, the differing approaches to international challenges may aggravate the crisis in bilateral relations among member states and, consequently, negatively affect the prospects for developing EU policies. For instance, Berlin and Warsaw have had very 
different ideas on how to respond to the challenge Donald Trump's presidency poses to Europe, the impact and course of European defence integration and arms control policies (Buras \& Janning, 2018).

In the EU, the lack of unanimity in some policy areas tends to paralyse the decision-making process, or can effectively slow it down, thus preventing the achievement of goals that some states consider beneficial but others see as undesirable. One might recall two recent examples: the French-led veto on accession talks with Albania and North Macedonia in 2019 (Nielsen, 2019) and Poland's veto (supported by Hungary, Estonia and the Czech Republic) on the European Commission's proposal for a 2050 net zero carbon emission target (Keating, 2019). In both cases, bilateralism strongly affected states' orientation at the EU fora. However, as Aggestam and Bicchi (2019: 2) argue, a 'horizontal and informal pattern of cross-loading, which can accommodate contestation and unilateral [state] actions [within the EU] while remaining embedded in a European multilateral order', may serve as a balancing mechanism, facilitating system homeostasis. In other words, it may become the modus operandi for the system's self-regulation. For those states that contest further integration, one possible reason for remaining in the EU is the awareness of interdependence and the costs of breaking the ties.

The changing dynamic of the EU governance system has reinforced the horizontal, rather than vertical, interaction among actors. This, in turn, has meant the consolidation of the Union's 'state-centric nature'. Hence, the integration process is, once again, considerably affected by national interests defined in realist terms. In other words, the scope and dynamics of integration processes are subordinated to the following logic: the level of cooperation depends on the complementary nature of cooperating parties' interests. Cooperation is a function of mutual recognition of joint interest rather than mutual recognition of shared values (Waltz, 1993: 50-60). Crises tend to reinforce this logic and challenge the application of the fundamental EU communitarian principles, such as solidarity. In addition, Aggestam and Bicchi (2019: 1) argue that the 'implementation of the Lisbon Treaty in the context of a fragmenting consensus has led to an increase in Member States' reliance on informal practices, such as: cross-loading and small groupings of like-minded countries'.

\section{Interdependence as a factor shaping bilateral relations among EU member states}

The international relations literature (Rosecrance \& Stein, 1973; Makins \& Nye, 1976; Keohane \& Nye, 1977; Moravcsik, 1993, 1997; Young, 2019; Bellamy, 2019) provides us with an insightful, but not necessarily coherent, elaboration on how to define interdependence in studies related to multi- and bilateral interstate relations. Some scholars have claimed that international interdependence can promote peaceful coexistence (Keohane \& Nye, 1977) and enable faster institutionalisation of multilateralism. Interdependence as 
a constant feature in relations between various participants of the EU system 'assumes that the pattern of interdependent state preferences imposes a binding constraint on state behaviour' (Moravcsik, 1997: 520), and that it can be managed effectively through 'negotiated policy coordination' (Moravcsik, 1993: 474). Following this argument, countries seek policy integration if they are convinced it offers greater benefits than unilateral action or a mere loose coordination (Schimmelfennig, 2015: 180). One example of this logic is the 2004 EU enlargement. For the new member countries, EU accession meant a substantial improvement of their position in the system. It also allowed socioeconomic growth and enhanced political as well as strategic security. The socalled 'old' EU member states were, in turn, 'promoting accession because they considered enlargement to be in their long-term economic and geopolitical interest' (Moravcsik \& Vachudova, 2003: 43). In this context, European integration is a mechanism for managing interdependence by cushioning the asymmetries between cooperating states (Schimmelfennig, Leuffen \& Rittberger, 2015).

The optimisation of the way interdependence is governed and managed occurs through the institutionalisation of cooperation. However, supranational institutionalisation of the system's structure, such as is the case with the European system, may limit member states' leeway. The supranational model is only one of the possible scenarios for the operationalisation of interdependence, whereby high levels of reciprocity among parties are not merely suggested but practically required. In a sense, this scenario is founded on 'wishful thinking' type of perception of European integration, as a neverending, progressive process in which development relies on inexhaustible internal resources and a lack of serious threats in the environment.

Another possible form for the operationalisation of interdependence within the EU is bilateralism, or 'small group cooperation' ('minilateralism'). Whereas the former emphasises the importance of horizontal interactions and exchange, the latter relies on the vertical dynamic. Internal EU alliances - small group cooperation - can be expressions of the weaknesses of EU institutionalism, though this does not necessarily have to be the case. Minilateralism can be simply thought of as an alternative or additional form of operationalising states' activity within the EU. Specific phenomena, such as regionalisation, associated with planning and implementing state policies in conjunction with the regional system of power, can serve as an example of such operationalisation. They may lead to the fragmentation of the European system's structure or, in contrast, become an impulse for consolidation.

Meanwhile, realists see the international system as an arena for rivalry rather than peaceful coexistence. They consider interdependence a mechanism for keeping the system in balance. In such a view, it is a function of states' equal capacities. An important precondition for interdependence to occur is a diffraction of states' needs and resources conditioning their functions and roles (Rosecrance \& Stein, 1973: 3). ${ }^{2}$ If all states are alike, they cannot offer each other different commodities and services. It can be said 


\section{Joanna Dyduch}

that interdependence occurs when states are equal, but different. It reflects a certain status of relations between countries, keeping them tied and constructively engaged in a system's structuring process. An efficiently structured system allows governments to reduce costs and increase the effectiveness of international cooperation aimed at managing both economic and political interdependence. Although Waltz stresses the formal equality of states, he emphasises that they differ vastly in their capabilities (Waltz, 1979: 105). In the context of states' dynamic coexistence, these discrepancies shape interstate relations. This interpretation, which becomes increasingly popular in times of crisis, argues that, by restructuring the institutional architecture of the EU system and changing patterns of decision-making processes, the Lisbon Treaty reform institutionalises asymmetries and, to some extent, reproduces not merely interdependence but actual dependence between member states. Naturally, this has an impact on interstate relations. Introducing more majority voting and strengthening the EU's supranational institutions does not equalise member states' capabilities, even though it has the potential to harmonise interactions.

On the one hand, the increasing complexity of the European Union (not just in terms of the numbers of actors but also in terms of diversified interests, perspectives and visions of how to work together or how to cope with external challenges) enriches the governance system. On the other hand, it challenges even well-established bilateral relations. The 'multilateralisation' of bilateral relations changes the patterns of the benefit and cost distribution, creating a framework that fuels interdependence. European environmental and climate policies, serving as a framework for interactions and cooperation between member states, can function as a good example here. When a comprehensive and far-reaching strategy of energy transition, conceptualised and promoted by some EU member states, became a part of the conceptual and operational logic of the EU in this policy area, a certain adaptive pressure was imposed on all system participants, including those that, because of domestic circumstances, were not in favour of revolutionary solutions. The countries not strong enough to prevent EU policy change - and some are not technologically advanced enough to implement Brussels' policy objectives - need to enter into cooperation with more developed partners, which only increases their dependence on stronger players. In this sense, the mechanism of European governance not only institutionalises interdependence but also consolidates asymmetry. Of course, it does not mean that the asymmetrical nature of the relationship between states is unchangeable; but the more productive and technologically advanced a country is, the more ways it has to influence international cooperation and relations with other states.

To illustrate the possible directions of change, one may look at the evolving relationship between central and eastern European (CEE) states and their western counterparts, including Polish-German relations. The economic model developed in CEE states after the collapse of the Soviet bloc and their democratic transformation in the 1990s was based primarily on openness 
to foreign direct investment (FDI) and the availability of cheap but skilled labour, along with limited large-scale innovation capacity. This specific variant of capitalism, termed the dependent market economy (DME) by Nölke and Vliegenthart (2009), has resulted in certain advantages. However, the 2007/8 financial crisis and its aftermath made it clear that it also creates limitations and challenges for the sustainability of national economies. The international economic crises have become a turning point and catalyst for an economic model transition in all CEE states, but the extent of changes implemented by each government differed depending on its capabilities (Havlik \& Iwasaki, 2017). Crises followed by the rise of competition or outright rivalry transformed interdependence into a dependence. Minimising it and, instead, maximising the political and economic benefits from international cooperation (possibly also interdependence) at some point became a core conceptual element of CEE governments' strategic thinking, as had already been the case with the EU founding members - particularly Germany. This was done through the diversification of international cooperation, especially in the economic realm. The energy sector may serve as a good example: broadly defined, diversification has become a key policy principle, as countries seek to preserve their energy security (Dyduch \& Skorek, 2020). Competitive domination in relations with other actors is achievable through economic instruments. States' capabilities determine the scope of their struggles both as political actors and market players. A successful competitive strategy can change the structure of the international system and, therefore, the extent of interdependence. Consequently, 'confidence in economic ability and technical skills leads a country to aspire to a larger political role' (Waltz, 1993: 61) in relations with other states.

If it is assumed that interdependence is a relation between equals (Waltz, 1979), then dependence results from asymmetry. In any international political system, some of the major and minor states are closely interdependent, while others are heavily dependent. The lesson that can be drawn from the above-mentioned considerations could be framed as follows: 'dependence', understood as a variation of 'interdependence', may limit dependent states' multidimensional development and, at the same time, may help countries that are successful in controlling and shaping the asymmetric relationship with weaker partners pursue their interests. An acknowledged asymmetry resulting in an unsustainable division of costs and benefits may lower the level of mutual trust between cooperating states and, consequently, undermine their motivations to participate in joint commitments in the long run.

However, a growing asymmetry and consolidation of dependence-based relations can lead to disillusionment with an unbalanced distribution of costs and benefits. In the long-term perspective, this breeds tensions between actors and pushes the dependent ones to contest patterns of bilateral relations. Ultimately, it may result in the deligitimisation of cooperation rules, or even the deconstruction of either the entire system or its relevant parts. This, in turn, may lead to the demultilateralisation of relations between states. In 
the case of the European Union, it may lead to a 'de-Europeanisation' or 'renationalisation' of member states' policies, whereby the operationalisation of bilateral relations with other member states relies more on a state's own resources and individual national strategies (Alecu de Flers \& Müller, 2012). The course and character of those processes depend very much on the policy area: the more politicised a given policy sector is, the greater the influence of asymmetry on governments' behaviour towards one another.

One can easily imagine a situation in which states may want to utilise the economic dependence of others to pursue their own political interests or simply maximise gains from the relationship, without paying too much attention to the costs and losses incurred by the weaker partners or the cohesion of the system as a whole. This phenomenon correlates with customisation - one of several de-Europeanisation variants pointed out by Jańczak (2010), which can be described as governments' conscious 'adaptation of the EU to one's own needs'. In such a scenario, Europeanisation involving all member states is replaced with an asymmetrical renationalisation of the EU governance system, or counter-Europeanisation (Jańczak, 2010: 94). This process reflects the ability of particular member states to effectively control European integration so as to make it align with their own visions, needs and interests. Interestingly, the EU framework may be used by the dominant actors to more effectively shape patterns of relations with other member states, also on the bilateral level. Meanwhile, when the advanced interdependence between actors within the EU system of governance evolves into asymmetrical relations and eventually takes the form of e the dominant method of cooperation changes. Unlike interdependence, dependence is not necessarily managed through 'negotiated policy coordination'. Its dynamic relies more on pressure and is defined by the power and capabilities of interacting partners.

When analysing Polish-German relations, Szwed argues that asymmetry between states creates room for disagreements across different policy areas - those related to high politics but also those concerning economically oriented public policies (EU budget, agriculture, environment, social policy and taxation) (Szwed, 2019). Moreover, Szwed claims that asymmetry inside the European project resulted not only from states' varying capabilities but also from their different 'seniority' statuses. For instance, as a latecomer that joined the Union in 2004, Poland was required to take on board the existing acquis and membership obligations, which it, naturally, had no role in shaping (Szwed, 2019: 65). The newcomers were expected primarily to adjust to EU standards according to EU norms. It is worth remembering that these norms and standards were defined and agreed on by the Union's founding members, and, as such, they reflect the interests and preferences of the 'old' member states.

International economic cooperation is a tool to pursue national interests rather than increase the interdependence (which sometimes occurs simply as a side effect) or introduce more international rules and institutions. In order 
to cope with external pressures (also political), countries must have sturdy economies. Governments must support these economies internally and promote them externally. A highly stable and efficient national economy is a precondition for pursuing goals through interactions with other state and non-state actors. By increasing the competitiveness and effectiveness of the state's economy, it is possible to decrease international political dependence, while at the same time maximising the economic benefit to be extracted from international cooperation.

If we assume that the EU member states try to use competitive advantages rooted in their own resources (e.g. population or market size) or capabilities (e.g. innovativeness), and strive not only to pursue their own interests but also to balance them with the demands and pressures from other countries, we can attempt to assess the EU governance system through the lens of the balance of power dynamics. Nevertheless, an analysis of bilateralism in the conditions of European integration requires us to depart slightly from the traditional understanding of the concept of a balance of power. Observation of the EU dynamics reveals the existence of ongoing interstate struggles for a desirable position in the system. It also shows how member states form a spectrum from the more to the less successful ones, or from the stronger to weaker players. The rules of the game are determined by the strategies of more powerful actors, which, for example, gain stronger and more efficient representation in EU institutions. As noted by Efremova, three variants of bilateral interactions between 'great powers" ${ }^{3}$ (state actors that are dominant in the system) and 'small states' can be identified: ${ }^{4}$ (1) mutual cooperation, achievable only when the actors trust one another; (2) mutual deterrence, when parties do not trust each other and try to minimise their potential losses if the opponent resorts to unilateral actions; and (3) unilateral actions, when one party gains full advantage over the other, which had not expected the opponent to defect (Efremova, 2019: 111). Interstate relations within the EU very rarely take on the third form; the first and second variants remain predominant. This reinforces the systemic asymmetry in the relations between member states but allows the system to maintain relative cohesion and reproduce its structures. Although a strong unilateral action on the part of one member state may undermine the stability of the system in the long run, it may also prove to be constructive or even transformative. If governments pursue 'only their own goals without any reference to the rest of the system, the linkages between them decline' (Rosecrance \& Stein, 1973: 5). However, if a member state launches unilateral initiatives and creates informal groupings within the EU while respecting the Union's organisational culture, it can enhance the system rather than undermine it (Aggestam \& Bicchi, 2019: 15).

Given the dynamic nature of both the international system at large and the European subsystem, a leadership position within the system is sometimes achieved by design, but on some occasions it may be unintended. It may happen that states are reluctant to dominate or lead, since being a leader or 
hegemon is not without its price; it requires a constant mobilisation and readiness to defend one's position, which is very often contested and questioned by other actors in bilateral and multilateral actions. The German example seems to illustrate this phenomenon. Berlin's leadership is becoming more evident in the EU system of governance, but is clearly limited to political economy, as noted by Green: ${ }^{5}$ until recently '[i]n no sense had Germany shown any readiness to play any strategic geopolitical role in the world of foreign affairs of the kind both the British and the French have taken for granted' (Green, 2016). Germany's somewhat ambivalent position has been termed 'reluctant leadership' (Newman, 2015; Buras, 2018).

The dominance of one state may also be the result of an adaptation by a weaker/smaller one - the so-called 'bandwagon' strategy (Waltz, 1993: 79). Under certain circumstances, states choose to follow or stand behind a strong partner in order to reduce their own individual costs of international activity. In these cases, their individual room for manoeuvre is rather limited, but they see such an asymmetric relationship as sufficiently beneficial. However, any loss of the leader's power may unbalance the system and encourage, or even force, weaker/smaller states to strengthen their position. Nonetheless, asymmetrical relations between states do not exclude the possibility of reverse influence and pressure (Efremova, 2019: 117), which means smaller states may influence their stronger and more powerful partners. Moreover, in the European system the phenomenon of influencing is not just bidirectionalhorizontal but also multidirectional, as it utilises the vertical Europeanisation mechanism. Therefore, apart from means typical for traditional bilateralism, such as the mutual exchange of services or joint agenda setting to secure international interests and positions, member states may involve the EU institutions (EU Court of Justice, European Commission) in order to shape other governments' behaviours.

\section{Conclusions}

This chapter argues that the bilateral relations between EU member states are heavily dependent on the Union's institutional, legal and political system of governance. Bilateralism in the EU is influenced, either directly or indirectly, by processes related to or caused by European integration. In the case of the EU governance system, bilateralism is deeply embedded in the multilateral context of the advanced, institutionalised integration process. Hence, one needs to acknowledge the cross-loading, horizontal interactions but cannot ignore the vertical dimension, which clearly involves the supranational institutional and normative framework (with a primary role played by EU institutions).

Although cross-loading Europeanisation is identified as an independent variable that may assist our understanding of bilateralism within the framework of European integration, one needs to remember interdependence - another 
crucial driver of bilateralism among EU member states. The EU's specific governance system, with its variety of platforms, mechanisms and instruments of interactions, creates new (operational rather conceptual) circumstances for bilateralism. This means that, though European integration has not altered the interest-driven nature of relations between states, it has reshaped the framework for bilateralism.

European integration may have several consequences for the development of interdependence or its extreme version, dependence. Above all, it has reduced the system's anarchy, as Europeanisation has offered new mechanisms and instruments applicable to bilateral and multilateral cooperation between member states. Governments have been provided with an institutionalised means of cost and benefit distribution, which makes the outcome of the relations more predictable. This helps to stabilise the system itself.

Although the chapter assumes a specific and rather narrow interpretation of the two variables in their most commonly identified form, shaped by the liberal intergovernmental and neorealist traditions respectively, it delivers analytical clarity in terms of cross-loading and interdependence - as both a concept and phenomenon. Nonetheless, finding additional, more nuanced ways to study bilateralism in the EU by using Europeanisation and interdependence as explanatory variables is still a worthwhile endeavour. Here one may refer to a large body of literature on the 'open method of coordination' (OMC) (Kröger, 2009), which as a concept may at least partly overlap with cross-loading but, at the same time, offers additional insights and analytical inspiration. Another potential area for further, more in-depth studies on the specific dynamics of interdependence as a factor shaping interstate relations within the EU can be found in the scholarly discussion on 'dimensions of power' (Haugaard, 2012). Finally, by extending the theoretical framework of analysis, one should make use of the explanatory potential of 'asymmetrical interdependence'. In this respect, in order to maintain the analytical precision and clarity of independent variables, this chapter has focused on interdependence and its variations rather than on asymmetry and interdependence separately.

\section{Notes}

1 Power-based relations are seen here as the opposite model to norms-based relations.

2 In this context, one may recall the concept of 'asymmetric interdependence', proposed first by Keohane and Nye (1973) and later widely utilised by political economists and public policies scholars. Here, 'asymmetry' refers to the fact that one party needs the benefits derived from a relationship more than the other (Wagner, 1988).

3 'Great powers': actors that dominate the system.

4 'Small states': actors that lack both the capacity and the political will to act offensively and to exert a decisive influence on others.

5 Stephen Green, a former British trade minister. 


\section{References}

Aggestam, L., \& Bicchi, F. (2019). 'New directions in EU foreign policy governance: cross-loading, leadership and informal groupings', Journal of Common Market Studies, 57(3), 1-18.

Alecu de Flers, N., \& Müller, P. (2012). 'Dimensions and mechanism of the Europeanization of member state foreign policy: state of the art and new research avenues', Journal of European Integration, 34(1), 19-35.

Bátora, J., \& Hocking, B. (2009). 'EU-oriented bilateralism: evaluating the role of member state embassies in the European Union', Cambridge Review of International Affairs, 22(1), 163-182.

Bellamy, R. (2019). 'Cosmopolitism and statism: global interdependence and national self-determination', in A Republican Europe of States: Cosmopolitism, Intergovernmentalism and Democracy in the EU (27-52). Cambridge: Cambridge University Press.

Buras, P. (2018). 'Reluctant leadership', Eastwest.eu, 26 August. Available at: https:// eastwest.eu/en/reluctant-leadership.

Buras, P., \& Janning, J. (2018). 'Divided at the centre: Germany, Poland, and the troubles of the Trump era', policy brief. London: European Council on Foreign Relations. Available at: www.ecfr.eu/page/-/divided_at_the_centre_germany_poland_and_ the_troubles_of_the_trump_era.pdf.

Dyduch, J., \& Skorek, A. (2020). 'Go South! Southern dimension of the V4 states' energy policy strategies: an assessment of viability and prospects', Energy Policy, 140, article 111372. Available at: https://doi.org/10.1016/j.enpol.2020.111372.

Efremova, K. (2019). 'Small states in great power politics: understanding the "buffer effect"', Central European Journal of International and Security Studies, 13(1), 100-121.

Featherstone, K., \& Radaelli, C. M. (eds.) (2003). The Politics of Europeanization. Oxford: Oxford University Press.

Green, S. (2016). Reluctant Meister: How Germany's Past Is Shaping Its European Future. London: Haus.

Hadeed, M., \& Sus, M. (2020). 'The transformation of political elites in the European Union after 2008: what is next after the constraining dissensus?', Journal of European Integration. doi: 10.1080/07036337.2020.1784155.

Haugaard, M. (2012). 'Rethinking the four dimensions of power: domination and empowerment', Journal of Political Power, 5(1), 33-54.

Havlik, P., \& Iwasaki, I. (eds.) (2017). Economics of European Crises and Emerging Markets. New York: Palgrave Macmillan.

Herbut, M., \& Kunert-Milcarz, R. (2017). 'The explanatory power of structural realism in the 21st century: the Eastern partnership, Russian expansionism and the war in Ukraine', Polish Political Science Yearbook, 46(2), 190-204.

Hill, C., and Smith, M. (2011). 'Acting for Europe: reassessing the European Union's place in international relations', in Hill, C., and Smith, M. (eds.), International Relations and the European Union (388-406). Oxford: Oxford University Press.

Howell, K. E. (2004). 'Uploading, downloading or crossloading? Conceptualizing Europeanization and European integration', in Europeanization, European Integration and Financial Services: Developing Theoretical Frameworks and Synthesising Methodological Approaches (41-59). London: Palgrave Macmillan. 
Jańczak, J. (2010). 'Przeciweruropeizacja jako kategoria badawcza w studiach nad procesami integracji europejskiej', in Pacześniak, A., \& Riedel, R. (eds.), Europeizacja: Mechanizmy, Wymiary, Efekty (pp. 93-105). Toruń: Wydawnictwo Adam Marszałek.

Joseph, J., \& Wight, C. (2010). 'Scientific realism and international relations', in Joseph, J., \& Wight, C. (eds.), Scientific Realism and International Relations (1-30). Basingstoke: Palgrave Macmillan.

Keohane, R. O., \& Nye, J. S. (1973). 'Power and interdependence', Survival: Global Politics and Strategy, 15(4), 158-165.

Keohane, R. O., \& Nye, J. S. (1977). Power and Interdependence: World Politics in Transition. Boston: Little, Brown.

Keating, D. (2019). 'EU Decarbonization Plan for 2050 collapses after Polish veto', Forbes, 20 June. Available at: www.forbes.com/sites/davekeating/2019/06/20/eudecarbonisation-plan-for-2050-collapses-after-polish-veto/\#2b2dad9830b2.

Kröger, S. (2009). 'The open method of coordination: underconceptualisation, overdetermination, de-politicisation and beyond', European Integration online Papers (EIoP), 13(5). Available at: https://ssrn.com/abstract=1553795.

Krotz, U., \& Schild, J. (2012). Shaping Europe: France, Germany, and Embedded Bilateralism from the Elysée Treaty to Twenty-First Century Politics. Oxford: Oxford University Press.

Krotz, U., \& Schild, J. (2018). 'Back to the future? Franco-German bilateralism in Europe's post-Brexit union, June 2018', Journal of European Public Policy, 25(8), 1174-1193.

Ladrech, R. (2010). Europeanization and National Politics. Basingstoke: Palgrave Macmillan.

Makins, C. J., \& Nye, J. S. (1976). 'Interdependence: the European example', Foreign Policy, 24, 139-144.

Major, C. (2005). 'Europeanisation and foreign and security policy: undermining or rescuing the nation state?', Politics, 25(3), 175-190.

Marciacq, F. (2012). 'The political geographies of Europeanisation: mapping the contested conceptions of Europeanisation', Journal of Contemporary European Research, 8(1), 57-74.

My, K. B., Verchere, A., \& Bertrand, S. (2009). 'Does bilateralism foster co-operation in Europe? An experimental approach of comparative merits of bilateralism and multilateralism'. Journal of Common Market Studies, 47(4), 891-910.

Moravcsik, A. (1993). 'Preferences and power in the European Community: a liberal intergovernmentalist approach', Journal of Common Market Studies, 31(4), 473-524.

Moravcsik, A. (1997). 'Taking preferences seriously: a liberal theory of international politics', International Organization, 51(4), 513-553.

Moravcsik, A., \& Vachudova, M. A. (2003). 'National interests, state power, and EU enlargement', East European Politics and Societies, 17(1), 42-57.

Moumoutzis, K. (2011). 'Still fashionable yet useless? Addressing problems with research on the Europeanization of foreign policy', Journal of Common Market Studies, 49(3), 607-629.

Moumoutzis, K., \& Zartaloudis, S. (2016). 'Europeanization mechanisms and process tracing: a template for empirical research' Journal of Common Market Studies, 54(2), 337-352. 
Newman, A. (2015). 'The reluctant leader: Germany's euro experience and the long shadow of reunification', in Matthias, M., \& Blyth, M. (eds.), The Future of the Euro (117-135). Oxford: Oxford University Press.

Nielsen, N. (2019). 'EU fails to deliver on Albania and North Macedonia', EUobserver, 18 October. Available at: https://euobserver.com/enlargement/146329.

Nölke, A., \& Vliegenthart, A. (2009). 'Enlarging the varieties of capitalism: the emergence of dependent market economies in east central Europe', World Politics, 61(4), 670-702. doi: 10.1017/S0043887109990098.

Olsen, J. P. (2002). 'The many faces of Europeanization', Journal of Common Market Studies, 40(5), 921-952.

Pannier, A. (2020). 'Bilateral relations', in Balzacq, T., Charillon, F., \& Ramel, F. (eds.), Global Diplomacy: An Introduction to Theory and Practice (19-34). Basingstoke: Palgrave Macmillan.

Pomorska, K. (2011). 'Poland: learning to play the Brussels game', in Wong, R., \& Hill, C. (eds.), National and European Foreign Policies: Towards Europeanization (167-188). London: Routledge.

Radaelli, C. M. (2004). 'Europeanisation: solution or problem?', European Integration online Papers (EIoP), 8(16). Available at: https://papers.ssrn.com/sol3/papers. cfm?abstract_id $=601163$.

Renard, T. (2015). 'Partnerships for effective multilateralism? Assessing the compatibility between EU bilateralism, (inter-)regionalism and multilateralism', Cambridge Review of International Affairs, 29(1), 1-18.

Rosecrance, R., \& Stein, A. (1973). 'Interdependence: myth and reality', World Politics, 26(1), 1-27.

Saurugger, S., \& Radaelli, C. (2008). 'The Europeanization of public policies: introduction', Journal of Comparative Policy Analysis: Research and Practice, 10(3), 213-219.

Schimmelfennig, F. (2015). 'Liberal intergovernmentalism and the euro area crisis', Journal of European Public Policy, 22(2), 177-195.

Schimmelfennig, F., Leuffen, D., \& Rittberger, B. (2015). 'The European Union as a system of differentiated integration: interdependence, politicization and differentiation', Journal of European Public Policy, 22(1), 1-21.

Skordas, A. (2018). 'The European Union as post-national realist power', in Blockmans, S., \& Koutrakos, P. (eds.), Research Handbook on the EU's Common Foreign and Security Policy (394-444). Cheltenham: Edward Elgar.

Smith, M. E. (2000). 'Conforming to Europe: the domestic impact of EU foreign policy co-operation', Journal of European Public Policy, 7(4), 613-631.

Smith, M. E. (2004). 'Toward a theory of EU foreign policy-making: multi-level governance, domestic politics, and national adaptation to Europe's common foreign and security policy', Journal of European Public Policy, 11(4), 740-758.

Szwed, S. (2019). Poland, Germany and State Power in Post-Cold War Europe: Asymmetry Matters. New York: Palgrave Macmillan.

Treaty on the Functioning of the European Union (2009). Available at: https://eur-lex. europa.eu/legal-content/EN/TXT/?uri=celex $\% 3 \mathrm{~A} 12012 \mathrm{E} \% 2 \mathrm{FTXT}$.

Uilenreef, A. (2016). 'Multiple bilateralism within the European Union: the Dutch coalition-building network during the budget negotiations', Journal of Common Market Studies, 54(2), 426-443.

Vink, M. P., \& Graziano, P. (eds.) (2007). Europeanization: New Research Agendas. Basingstoke: Palgrave Macmillan. 
Wagner R. H. (1988). 'Economic interdependence, bargaining power, and political influence'. International Organization, 42, 461-483.

Waltz, K. N. (1979). Theory of International Politics. Reading, MA: Addison-Wesley.

Waltz, K. N. (1993). 'The emerging structure of international politics', International Security, 18(2), 44-79.

Young, O. R. (2019), 'Interdependencies in world politics', in Maghroori, R., \& Ramberg, B. (eds.), Globalism versus Realism: International Relations’ Third Debate (57-80). New York: Routledge. 